\title{
Manganese as Substitute for Magnesium During Magnesium-limited Growth of the Cyanobacterium Anacystis nidulans
}

\author{
By HANS CHRISTIAN UTKILEN \\ Botanical Institute, University of Oslo, P.O. Box 1045, Blindern, Oslo 3, Norway
}

(Received 3 December 1982; revised 20 January 1983)

\begin{abstract}
An apparent inhibition of cell division in the cyanobacterium Anacystis nidulans, caused by low $\mathrm{Mg}^{2+}$ concentrations, was abolished by increasing the medium $\mathrm{Mn}^{2+}$ concentration. Thus the mean cell volume of this organism growing in a $\mathbf{M g}^{2+}$-limited chemostat culture decreased from an average of 1.3 to $0.4 \mu \mathrm{m}^{3}$ following an increase in the reservoir $\mathrm{Mn}^{2+}$ concentration from 9.5 to $15 \mu \mathrm{M}$. This increase in $\mathrm{Mn}^{2+}$ had no effect on the steady-state biomass concentration, while a further elevation of the $\mathrm{Mn}^{2+}$ concentration lowered the biomass concentration, seemingly by making $\mathrm{Mg}^{2+}$ less available to the organism. The cellular $\mathbf{M n}^{2+}$ concentration increased, while cellular $\mathbf{M g}^{2+}$ was unaltered, following an increase in the medium $\mathbf{M n}^{2+}$ concentration.
\end{abstract}

\section{INTRODUCTION}

Although $\mathrm{Mn}^{2+}$ cannot replace $\mathrm{Mg}^{2+}$ for growth (Tempest, 1969; Utkilen, 1982), there is evidence indicating that $\mathrm{Mg}^{2+}$ can be replaced by $\mathrm{Mn}^{2+}$ in some cellular processes (Kennell \& Kotoulas, 1967; Webb, 1968). Cell division could be one of the events where $\mathrm{Mn}^{2+}$ might substitute for $\mathrm{Mg}^{2+}$. Deprivation of either $\mathrm{Mn}^{2+}$ (Alberts-Dietert, 1941) or $\mathbf{M g}^{2+}$ (Finkle \& Appleman, 1953) resulted in cell enlargement of Chlorella, and cell enlargement was also found when a diatom was deprived of $\mathrm{Mn}^{2+}$ (Von Stosch, 1942).

In the cyanobacterium Anacystis nidulans, cell division is influenced by $\mathrm{Mg}^{2+}$ (Utkilen, 1982) and cell division was dissociated from biomass production when the organism was grown in media containing $5 \mu \mathrm{M}-\mathrm{Mg}^{2+}$. In order to examine whether $\mathrm{Mn}^{2+}$ could replace $\mathrm{Mg}^{2+}$ in cell division of $A$. nidulans, the concentration of $\mathrm{Mn}^{2+}$ in the growth medium of a chemostat limited by $\mathrm{Mg}^{2+}$ was progressively increased.

\section{METHODS}

Organism. Anacystis nidulans strain UTEX 625 of the Culture Collection of Algae, Department of Botany, University of Texas, was used.

Growth conditions. The organism was grown in a $\mathrm{Mg}^{2+}-$ limited chemostat as described earlier (Utkilen, 1982). The feed medium was designed to give a final concentration of $5 \mu \mathrm{M}-\mathrm{MgCl}_{2}$, but when the $\mathrm{Mg}^{2+}$ concentration in feed medium was measured it turned out to be about $6 \mu \mathrm{M}$ (Table 1). The difference between added and measured $\mathrm{Mg}^{2+}$ could be due to impurities from other chemicals, but the assay errors were large ( 25 and $15 \%$ ), which also might account for some of the difference. The desired $\mathbf{M n}^{2+}$ concentration was obtained by adding $\mathrm{MnCl}_{2}$, which was autoclaved separately unless otherwise stated.

Cell number and volume. These were determined by a Coulter electronic particle counter (Model $\mathrm{Z}_{\mathrm{B}}$, industrial, Coulter Electronics Ltd, U.K.), as described earlier (Utkilen, 1982).

Analytical methods. Macromolecule and dry weight estimations were performed as previously described (Utkilen, 1982). $\mathrm{Mn}^{2+}$ and $\mathrm{Mg}^{2+}$ were determined by atomic absorption spectrophotometry (Perkin Elmer 306, Connecticut, U.S.A.), using air/acetylene.

\section{RESULTS AND DISCUSSION}

Marler \& Van Baalen (1965) showed that about $60 \mu \mathrm{g} \mathrm{H}_{2} \mathrm{O}_{2} 1^{-1}$ was formed in medium $\mathrm{C}$ (Kratz \& Meyers, 1955) during autoclaving. This was due to a reaction between citrate and 
Table 1. $\mathrm{Mn}^{2+}$ and $\mathrm{Mg}^{2+}$ concentrations in feed medium and culture medium, when $9 \cdot 5$ or 20 $\mu \mathrm{M}-\mathrm{Mn}^{2+}$ was added to the reservoir of a chemostat limited by $6 \mu \mathrm{M}-\mathrm{Mg}^{2+}\left(D=0.01 \mathrm{~h}^{-1}\right)$

The steady-state cell number at the two $\mathrm{Mn}^{2+}$ concentrations is also shown. The concentrations of the cations are given \pm S.D. (six determinations), while cell numbers are average values obtained from two samples.

\begin{tabular}{|c|c|}
\hline \multicolumn{2}{|c|}{$\begin{array}{c}\text { Concn }(\mu \mathrm{M}) \\
\text { in feed medium }\end{array}$} \\
\hline $\mathrm{Mg}^{2+}$ & $\mathrm{Mn}^{2+}$ \\
\hline $6.0 \pm 1 \cdot 5$ & $4 \cdot 7 \pm 0$ \\
\hline $6.0 \pm 0.9$ & $13 \cdot 2 \pm 0$ \\
\hline
\end{tabular}

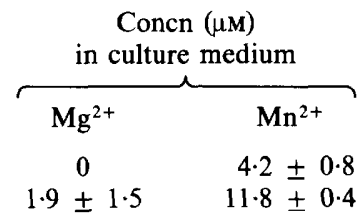

$10^{-7} \times$ No. of
cells $\mathrm{ml}^{-1}$
$4 \cdot 0$
$10 \cdot 1$

$\mathrm{Mn}^{2+}$. The same authors demonstrated that the growth of $A$. nidulans was extremely sensitive to $\mathrm{H}_{2} \mathrm{O}_{2}$. In order to examine whether increasing the $\mathrm{Mn}^{2+}$ concentration would have any inhibitory effect as a consequence of such a reaction, the concentration of this cation was increased to $20 \mu \mathrm{M}(9 \cdot 5 \mu \mathrm{M}$ in medium $\mathrm{C})$ in the reservoir before or after autoclaving. The results revealed that the steady-state biomass was about $80 \mu \mathrm{g} \mathrm{ml}^{-1}$ and the chlorophyll content $0.8 \%$ of dry weight in both cases. The different ways of handling $\mathrm{Mn}^{2+}$ therefore had no effect on the growth of $\boldsymbol{A}$. nidulans. As a result of these preliminary experiments the additional amount of $\mathrm{Mn}^{2+}$ was autoclaved separately, since there was a heavy precipitation during autoclaving media that contained $20 \mu \mathrm{M}-\mathrm{Mn}^{2+}$.

The steady-state dry weight for the $\mathrm{Mg}^{2+}$-limited $(6 \mu \mathrm{M})$ chemostat at $D=0.1 \mathrm{~h}^{-1}$ was

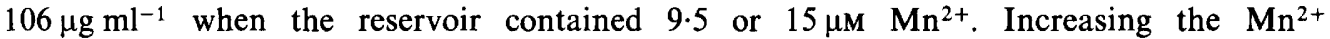
concentration to 20 or $100 \mu \mathrm{M}$ reduced the steady-state dry weight to $85 \mu \mathrm{g} \mathrm{ml}^{-1}$. The reduction in steady-state biomass was caused by an inhibition of $\mathrm{Mg}^{2+}$ uptake, since $\mathbf{M g}^{2+}$ was detected in the culture medium at $20 \mu \mathrm{M}-\mathrm{Mn}^{2+}$ (Table 1). It was also found that the $\mathrm{Mn}^{2+}$ concentration in the feed medium was about 5 or $13 \mu \mathrm{M}$, when 9.5 or $20 \mu \mathrm{M}-\mathrm{Mn}^{2+}$, respectively, was added to the reservoir (Table 1). This difference, which was not found for $\mathrm{Mg}^{2+}$, could be due to precipitation in the reservoir. These results indicate that $\mathrm{Mn}^{2+}$ had a constant inhibitory effect on biomass production of $A$. nidulans over a wide range of concentrations above $13 \mu \mathrm{M}$ in a chemostat limited by $6 \mu \mathrm{M}-\mathrm{Mg}^{2+}$.

The most pronounced effect of increasing the $\mathrm{Mn}^{2+}$ concentration was on mean cell volume, since increasing the reservoir $\mathrm{Mn}^{2+}$ concentration from 9.5 to $15 \mu \mathrm{M}$ resulted in a decrease of cell volume from about 1.4 to $0.4 \mu \mathrm{m}^{3}$. These minute cells were also obtained with 20 or $100 \mu \mathrm{M}$ $\mathrm{Mn}^{2+}$ in the reservoir. These cell sizes and the results in Table 1 were used to calculate intracellular concentrations of $\mathrm{Mn}^{2+}$ and $\mathrm{Mg}^{2+}$. The cellular $\mathrm{Mg}^{2+}$ concentration was found to be about $100 \mathrm{mM}$ at both 5 and $13 \mu \mathrm{M}-\mathrm{Mn}^{2+}$, while the cellular $\mathrm{Mn}^{2+}$ concentration increased from about 9 to $35 \mathrm{~mm}$ over the same range of extracellular $\mathrm{Mn}^{2+}$ concentrations. Thus, although the cellular $\mathrm{Mn}^{2+}$ concentration increased almost fourfold, the organism was able to maintain its $\mathrm{Mg}^{2+}$ concentration. But $A$. nidulans could no longer deplete the medium of $\mathrm{Mg}^{2+}$ at $13 \mu \mathrm{M}-\mathrm{Mn}^{2+}$ or higher. A competitive inhibition of $\mathrm{Mg}^{2+}$ uptake by $\mathrm{Mn}^{2+}$ was unlikely, since the lowering of biomass concentration was the same with either 20 or $100 \mu \mathrm{M}-\mathrm{Mn}^{2+}$ in the reservoir.

The cell size of $A$. nidulans growing in a $\mathrm{Mg}^{2+}$-limited chemostat culture decreased with increasing growth rate, while it increased with growth rate when $\mathrm{SO}_{4}^{2-}$ was the limiting nutrient (Utkilen, 1982). The mean cell volume, as a function of growth rate in a $\mathrm{Mg}^{2+}$-limited chemostat culture with additional $\mathrm{Mn}^{2+}$, followed the same pattern as for a non- $\mathrm{Mg}^{2+}$-limited culture (Fig. 1). $\mathrm{A} \mathrm{Mg}^{2+}$ shift-up from $5 \mu \mathrm{M}$ to $1 \mathrm{mM}$, during balanced growth, resulted in a synchronized cell division of $\boldsymbol{A}$. nidulans after $90 \mathrm{~min}$ and was accompanied by a marked decrease in cell volume (Utkilen, 1982). In order to investigate whether $\mathrm{Mn}^{2+}$ would have the same effect on cell division, the organism was grown in batch cultures as described earlier (Utkilen, 1982) and $\mathrm{Mn}^{2+}$ shift-ups to $15,20,50$ and $100 \mu \mathrm{M}$ were made by adding $\mathrm{MnCl}_{2}$. These shifts revealed that the cell volume began to decline about 60 min after the $\mathrm{Mn}^{2+}$ shift-up, but the decrease in cell volume was not as marked as with a $\mathrm{Mg}^{2+}$ shift-up (Utkilen, 1982) and there was no synchronized cell division accompanying the decrease in cell volume. 


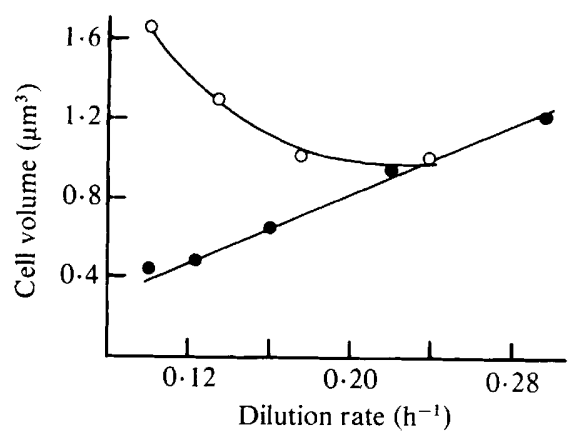

Fig. 1. Variation in mean cell volume with growth rate for a $\mathrm{Mg}^{2+}$-limited $(6 \mu \mathrm{M})$ chemostat of $A$. nidulans where the $\mathrm{Mn}^{2+}$ concentration in the reservoir was $9 \cdot 5 \mu \mathrm{M}(\mathrm{O})$ or $15 \mu \mathrm{M}(\mathcal{O})$.

The results presented here indicate that $\mathrm{Mn}^{2+}$ could functionally replace $\mathrm{Mg}^{2+}$ in the cell division process during $\mathrm{Mg}^{2+}$-limited growth. In doing so, $\mathrm{Mn}^{2+}$ was apparently more efficient than $\mathrm{Mg}^{2+}$, since very small cells were obtained although most of the added $\mathrm{Mn}^{2+}$ was not taken up by the organism (Table 1). Increasing the concentration of $\mathrm{Mg}^{2+}$, which was depleted from the medium, did not result in the same decrease of cell volume (Utkilen, 1982) though it resulted in a corresponding increase in biomass concentration (Utkilen, 1982). Therefore only a fraction of the additional $\mathrm{Mg}^{2+}$ would be available for cell division, in contrast to $\mathrm{Mn}^{2+}$ where no increase in biomass was observed. $\mathrm{Mn}^{2+}$ might in fact be less effective than $\mathrm{Mg}^{2+}$ in cell division, since no synchronized cell division was observed during a $\mathrm{Mn}^{2+}$ shift-up in contrast to that of a $\mathrm{Mg}^{2+}$ shift-up (Utkilen, 1982).

\section{REFERENCES}

Alberts-Dietert, F. (1941). Die Wirkung von Eisen und Mangan auf die Stickstoffassimilation von Chlorella. Planta 32, 88-117.

Finkle, B. J. \& Appleman, D. (1953). The effect of magnesium concentration on the growth of Chlorella. Plant Physiology 28, 664-673.

MARLER, J. E. \& VAN BAALEN, C. (1965). Role of $\mathrm{H}_{2} \mathrm{O}_{2}$ in single-cell growth of the blue-green alga, Anacystis nidulans. Journal of Phycology 1, 180-185.

KenNell, D. \& Kotoulas, A. (1967). Magnesium starvation of Aerobacter aerogenes I. Changes in nucleic acid composition. Journal of Bacteriology 93 , 334-344.

Kratz, W. A. \& Meyers, J. (1955). Nutrition and growth of several blue-green algae. American Journal of Botany 42, 282-287.
TEMPEST, D. W. (1969). Quantitative relationships between inorganic cations and anionic polymers in growing bacteria. Symposia of the Society for General Microbiology 19, 87-111.

UTKILEN, H. C. (1982). Magnesium-limited growth of the cyanobacterium Anacystis nidulans. Journal of General Microbiology 128, 1849-1862.

Von Stosch, H. A. (1942). Form und Formwechsel der Diatomee Achnantes longipes in Abhängigkeit von der Ernährung. Mit besonderer Berücksichtigung der Spurenstoffe. Berichte der Deutschen Botanischen Gesellschaft 60, 2-16.

WEBB, M. (1968). The influence of certain trace metals on bacterial growth and magnesium utilization. Journal of General Microbiology 51, 325-335. 